\title{
Binding of kidney bean (Phaseolus vulgaris) isolectins to differentiated human colon carcinoma Caco- 2 cells and their effect on cellular metabolism
}

\author{
H G C J M Hendriks, M J L Kik, J F J G Koninkx, T S G A M van den Ingh, J M V M Mouwen
}

\begin{abstract}
The binding of Phaseolus vulgaris (PHA) isolectins $L_{4}$ and $E_{4}$ to the brush border membrane of differentiated Caco-2 cells was studied and the impact on cellular metabolism and microvilli was assessed. Computer analysis of the data based on binding experiments with peroxidase conjugated isolectins gave mean (SD) values for maximal binding of 2540 (151). $10^{-9} M$ for PHA- $\mathrm{L}_{4}$ and 2104 (140). $10^{-9} M$ for PHA-E 4 per $\mathrm{mg}$ of brush border membrane protein. The dissociation constants for $L_{4}$ and $E_{4}$ binding were 4.3 $(1 \cdot 4) \cdot 10^{-6} \mathrm{M}$ and $1 \cdot 1(0 \cdot 8) \cdot 10^{-6} \mathrm{M}$, respectively. Incubation of differentiated Caco- 2 cells for 30 minutes with ferritin conjugated PHA isolectins showed that, as indicated by the number of ferritin particles, PHA-E 4 bound to the microvilli to a greater extent than PHA- $\mathrm{L}_{4}$. Ferritin particles were also localised intracellularly over endocytotic invaginations and vesicles. After incubation for 48 hours with PHA-L $_{4}$

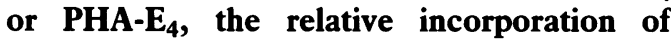
precursors for DNA, RNA, and (glyco)protein synthesis into the trichloroacetic acid insoluble fraction of the Caco-2 cells was determined. Both isolectins stimulated the incorporation of thymidine and glucosamine, but neither PHA-L $\mathrm{L}_{4}$ nor PHA-E 4 were able to influence the incorporation of uridine. With respect to fucose, methionine, and $\mathbf{N}$-acetyl mannosamine, the stimulatory effect remained confined to PHA-E $_{4}$. Since PHA- $\mathrm{L}_{4}$ and PHA-E 4 were tested at the same concentrations, $P H A-E_{4}$ is more effective than PHA-L $\mathrm{L}_{4}$. The changes in the uptake of radioactive precursors were lost after heat inactivation of PHA-E P $_{4}$ Compared with control and PHA- $\mathrm{L}_{4}$ incubated Caco-2 cells, the microvilli of PHA-E $\mathbf{F}_{\mathbf{4}}$ incubated cells were shortened significantly $(\mathbf{p}<0 \cdot 01)$.
\end{abstract}

Department of Veterinary Pathology, Faculty of Veterinary Medicine, University of Utrecht,
Uninary The Netherlands H G C J M Hendriks M J L Kik

J F J G Koninkx

T S G A M van den Ingh

J M V M Mouwen

Correspondence to:

Dr J F J G Koninkx,

Department of Veterinary

Pathology, Faculty of

Veterinary Medicine

University of Utrecht,

Yalelaan 1, Postbus 80.158,

3508 TD Utrecht, The

Netherlands.

Accepted for publication

26 March 1990
Lectins of plant origin, mostly present in food elements, sometimes induce severe damage to the intestinal tract unless their activity is destroyed by heating. ${ }^{1-5}$ In addition, lectins are known to interfere with cellular processes in different types of cells. ${ }^{6}$ Essentially all metabolic processes examined in Phaseolus vulgaris (PHA) treated lymphocytes are stimulated, though to varying degrees and at different times after exposure to the mitogen. ${ }^{7}$ There are relatively few studies on lectins in relation to the cellular metabolism in enterocytes. ${ }^{8-13}$ After binding of the dietary lectins through their sugar reactive sites to the enterocytes or the subsequent endocytosis of the lectin receptor complex, or both, ${ }^{14}$ disruption of the structure of the brush border takes place in vivo ${ }^{414}$ as well as in vitro. ${ }^{15}$

We have recently shown that because of the similarity between the lectin induced lesions in vivo and in vitro, the human colon carcinoma cell line Caco-2 may represent a suitable model for investigation of the multifold aspects of lectins in differentiated enterocytes. ${ }^{15}$

In the experiments presented in this study we have used differentiated Caco- 2 cells, which display both structural (microvilli, tight junctions) and functional (brush border enzymes) characteristics of small intestinal enterocytes, ${ }^{16}$ to investigate the binding of PHA isolectins $\mathrm{L}_{4}$ and $E_{4}$ to these cells and the subsequent lectin induced effects on the microvilli and the cellular metabolism. In particular, we have examined the effects of both isolectins on the DNA, RNA, and (glyco)protein synthesis using several specific radioactive precursors.

\section{Methods}

CACO- 2 CELl CULTURE

The Caco-2 cells were grown in Dulbecco's modified Eagle medium (DMEM) (Flow Laboratories, Amstelstad BV, Amsterdam, The Netherlands) supplemented with $1 \%(\mathrm{v} / \mathrm{v})$ nonessential amino acids (Flow), $50 \mu \mathrm{g}$ of gentamicin/ml (Flow), $10 \mathrm{mM}$ sodium bicarbonate (Flow), $25 \mathrm{mM}$ Hepes (Flow), and 20\% (v/v) fetal calf serum (FCS) (Sanbio BV, Uden, The Netherlands) and cultured at $37^{\circ} \mathrm{C}$ in a humidified atmosphere of $5 \% \mathrm{CO}_{2}$ in air. The cells were seeded at $4 \cdot 10^{4}$ cells $/ \mathrm{cm}^{2}$ using tissue culture 24 flat bottom well plates $\left(2 \mathrm{~cm}^{2} /\right.$ well $)$ (Gibco Europe BV, Hoofddorp, The Netherlands) or $75 \mathrm{~cm}^{2}$ tissue culture flasks (Costar Europe Ltd, Badhoevedorp, The Netherlands) containing 1 or $15 \mathrm{ml}$ of culture medium respectively. The culture medium was changed three times a week. This study encompassed 32 passages of the cell line ranging from the 69th to the 101st.

Since incubation of the differentiated Caco-2 cells with PHA isolectins should be carried out in medium lacking any carbohydrate sources, the percentage of FCS was gradually reduced, and at the same time the amount of the serum substitute Ultroser G (Reactifs IBF, LKB-Products BV, Zoetermeer, The Netherlands) was increased. On day 14 after cell seeding the culture medium containing $20 \%(\mathrm{v} / \mathrm{v})$ FCS was replaced by $1 \mathrm{ml}$ of culture medium containing $10 \%(\mathrm{v} / \mathrm{v}) \mathrm{FCS}$ and $1 \%(\mathrm{v} / \mathrm{v})$ Ultroser $\mathrm{G}$, on day 16 it was replaced by $1 \mathrm{ml}$ of culture medium containing $1 \%(\mathrm{v} / \mathrm{v})$ FCS and $2 \%(\mathrm{v} / \mathrm{v})$ Ultroser $\mathrm{G}$ and on day 19 by $0.5 \mathrm{ml}$ of DMEM. 
INCUBATION OF DIFFERENTIATED CACO-2 CELLS BY PHA ISOLECTINS $\mathrm{L}_{4}$ AND $\mathrm{E}_{4}$

Incubation of the cells was performed in quadruplicate in $0.5 \mathrm{ml}$ of DMEM containing 0 , $40,80,120,160$, and $200 \mu \mathrm{g}$ of $\mathrm{PHA}^{-\mathrm{L}_{4}} / \mathrm{ml}$ or PHA-E $/$ /ml (E-Y Laboratories Inc, San Mateo, California, USA). For concentrations lower than $500 \mu \mathrm{g} / \mathrm{ml}, \mathrm{PHA}^{-\mathrm{L}_{4}}$ shows no agglutination with human erythrocytes whereas $\mathrm{PHA}-\mathrm{E}_{4}$, at a concentration of less than $20 \mu \mathrm{g} / \mathrm{ml}$, agglutinates 3\% human erythrocytes (product information).

After incubation for 44 hours, $100 \mu \mathrm{l}$ of DMEM containing ${ }^{14} \mathrm{C}$-thymidine ${ }^{\star}(0.02 \mu \mathrm{Ci})$ and ${ }^{3} \mathrm{H}$-glucosamine ${ }^{\star}(0.8 \mu \mathrm{Ci}),{ }^{14} \mathrm{C}$-uridine ${ }^{\star}$ $(0.02 \mu \mathrm{Ci})$ and ${ }^{3} \mathrm{H}$-fucose ${ }^{\star}(2 \mu \mathrm{Ci})$ or ${ }^{35} \mathrm{~S}$ methionine $^{\star}(0 \cdot 1 \mu \mathrm{Ci})$ and $\mathrm{N}$-acetyl ${ }^{3} \mathrm{H}$ mannosamine ${ }^{\star \star}(3 \mu \mathrm{Ci})$ were added to the monolayer and double labelling incubation was continued for four hours ( ${ }^{\star}$ Amersham Nederland BV, Houten, The Netherlands; $\star \star N$ New England Nuclear, Du Pont de Nemours BV, 's-Hertogenbosch, The Netherlands). The selection of the radioactive monosaccharides was made on the basis of their entry point in the metabolic pathway and the metabolic conversion to other monosaccharides. ${ }^{17}$ The incorporation was stopped by adding $1 \mathrm{ml}$ of $10 \%$ trichloroacetic acid $\left(0^{\circ} \mathrm{C}\right)$ to the monolayer. Subsequently, the monolayer was washed twice with $1 \mathrm{ml}$ of $0.01 \mathrm{M}$ PBS (0.01 $\mathrm{M} \mathrm{Na}_{2} \mathrm{HPO}_{4}, 0.01 \mathrm{M}$ $\mathrm{NaH}_{2} \mathrm{PO}_{4}, 0.9 \% \mathrm{NaCl}$ ), $\mathrm{pH} 7 \cdot 3$, fixed with $1 \mathrm{ml}$ of methanol for 10 minutes, and dissolved in $0.5 \mathrm{ml}$ of $0.1 \mathrm{~N} \mathrm{NaOH}$. The incorporated radioactivity present in $0.2 \mathrm{ml}$ of $0.1 \mathrm{~N} \mathrm{NaOH}$ was determined by liquid scintillation counting in $2 \mathrm{ml}$ of Dynagel (J T Baker Chemical BV, Deventer, The Netherlands) as scintillant and performed with a Beckman LS 1701 (Beckman Instruments BV, Mijdrecht, The Netherlands).

The incorporated radioactivity was calculated as disintegrations per minute/ $\mu \mathrm{g}$ of $\mathrm{DNA}^{18}$ and expressed as the relative incorporation (factor by which the incorporation was increased or decreased when compared with cell cultures that were not incubated with lectins).

The effect of the lectin concentrations on cell viability was determined by trypan blue exclusion.

\section{PREPARATION OF PURIFIED BRUSH BORDER}

MEMBRANES FROM DIFFERENTIATED CACO- 2 CELLS The cell monolayer was washed three times with $5 \mathrm{ml}$ of $0.01 \mathrm{M} \mathrm{PBS}, \mathrm{pH} 7.3$ at $37^{\circ} \mathrm{C}$ and the cells were removed from the surface of the culture flasks after incubation for 45 minutes at $37^{\circ} \mathrm{C}$ with $5 \mathrm{ml}$ of transfer medium $(8 \cdot 0 \mathrm{~g} \mathrm{NaCl}, 0.2 \mathrm{~g}$ $\mathrm{KH}_{2} \mathrm{PO}_{4}$, and $0.2 \mathrm{~g} \mathrm{Na}_{2}$ EDTA. $\left.2 \mathrm{H}_{2} \mathrm{O} / 1\right)$. The resulting cell pellet formed by centrifugation (10 minutes at $500 \mathrm{~g}$ ) at $4^{\circ} \mathrm{C}$ was washed and pelleted three times with $10 \mathrm{ml}$ of $0.01 \mathrm{M} \mathrm{PBS}, \mathrm{pH} 7.3$ $\left(4^{\circ} \mathrm{C}\right)$ and finally stored at $-70^{\circ} \mathrm{C}$. Highly purified brush border membranes were prepared according to a modification of an existing method. ${ }^{19}$ Briefly, the isolation procedure performed at $4^{\circ} \mathrm{C}$ consists of the following steps: homogenisation and ultrasonication in $2 \mathrm{mM}$ Tris-50 mM mannitol buffer, $\mathrm{pH} 7 \cdot 1 ; \mathrm{Ca}^{2+}$ treatment of the homogenate; centrifugation (10 minutes at $950 \mathrm{~g}$ and 30 minutes at $33500 \mathrm{~g}$ ); Tris disruption of brush border fragments; purification of the brush border membranes by gradient ultracentrifugation (15 minutes at $63000 \mathrm{~g}$ ); pelleting by centrifugation (60 minutes at $200000 \mathrm{~g}$ ) of the membrane fraction formed at the interface between $37 \%$ and $42 \%$ glycerol. The modification applied to the glycerol gradient. The gradient was composed of two layers: $1.5 \mathrm{ml} 37 \%$ glycerol and $5.5 \mathrm{ml} 42 \%$ glycerol in a separation medium of $0.05 \mathrm{M}$ $\mathrm{MgCl}_{2}$.

BINDING OF PEROXIDASE CONJUGATED PHASEOLUS VULGARIS ISOLECTINS TO THE BRUSH BORDER MEMBRANES OF DIFFERENTIATED CACO- 2 CELLS Purified brush border membranes (200000 $\mathrm{g}$ pellet $)^{19}$ were used to show the binding of the PHA isolectins $\mathrm{L}_{4}$ and $\mathrm{E}_{4}$. The lectin binding to the brush border membranes isolated from differentiated Caco- 2 cells has been determined quantitatively using the enzyme linked lectin sorbent assay (ELLSA). ${ }^{20}$

By means of a ligand programme the specific binding was calculated in saturation experiments from the untransformed total binding data and from the specific binding data using corrected free ligand concentrations. The data were fitted in a one binding site and a two binding sites model. The best fit (one binding site model) was chosen using least squares values that were statistically compared in an F test.

Inhibition studies were conducted using excess lectin specific monosaccharide. The nonspecific binding in this assay approximated $30 \%$ of the total binding.

BINDING OF FERRITIN CONJUGATED PHASEOLUS VULGARIS ISOLECTINS TO DIFFERENTIATED CACO-2 CELLS

Differentiated Caco- 2 cells were grown in tissue culture 24 flat bottom well plates on Thermanox tissue culture cover slips (Flow). After three

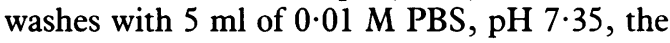
cell monolayers were incubated at $37^{\circ} \mathrm{C}$ for 30 minutes with $50 \mu \mathrm{g}$ of $\mathrm{PHA}-\mathrm{L}_{4}$ ferritin $/ \mathrm{ml}$ or $\mathrm{PHA}^{-\mathrm{E}_{4}}$ ferritin/ml in 0.01 M PBS, $\mathrm{pH} 7 \cdot 35$. The cells were subsequently rinsed three times with $1 \mathrm{ml}$ of $0.01 \mathrm{M} \mathrm{PBS}, \mathrm{pH} 7 \cdot 35$, and submitted to electronmicroscopic fixation and embedding procedures. After prefixation for 120 minutes with $0.5 \%(\mathrm{v} / \mathrm{v})$ glutaraldehyde in $0.1 \mathrm{M}$ phosphate buffer, $\mathrm{pH} 7 \cdot 35\left(4^{\circ} \mathrm{C}\right)$, post-fixation for 30 minutes with $2 \%(\mathrm{v} / \mathrm{v}) \mathrm{OsO}_{4}$ in $0 \cdot 1 \mathrm{M}$ phosphate-buffer, $\mathrm{pH} 7 \cdot 35\left(4^{\circ} \mathrm{C}\right)$, and dehydration the cell monolayer was embedded in Araldite. Fixation and embedding of the cell monolayers were performed in situ. ${ }^{1621}$

MORPHOLOGICAL CHANGES IN THE MICROVILLI OF DIFFERENTIATED CACO-2 CELLS AFTER

INCUBATION WITH PHA-ISOLECTINS

Differentiated Caco-2 cells grown in tissue culture 24 flat bottom well plates on Thermanox tissue culture cover slips were incubated at $37^{\circ} \mathrm{C}$ for 48 hours with $50 \mu \mathrm{g}$ of PHA- $\mathrm{L}_{4} / \mathrm{ml}$ or PHA-E $4 / \mathrm{ml}$ in $0.5 \mathrm{ml}$ of DMEM. Postincubation and subsequent electronmicroscopic 
Figure 1: Specific binding of peroxidase conjugated

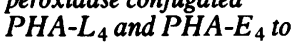
purified brush border membranes of differentiated Caco-2 cells.

These binding curves have been used for calculation of maximal lectin binding and dissociation constant.

Binding studies were carried out as described previously. ${ }^{20}$ bbm $=$ brush border membrane; $P H A-P O=$ peroxidase conjugated Phaseolus vulgaris agglutinin.

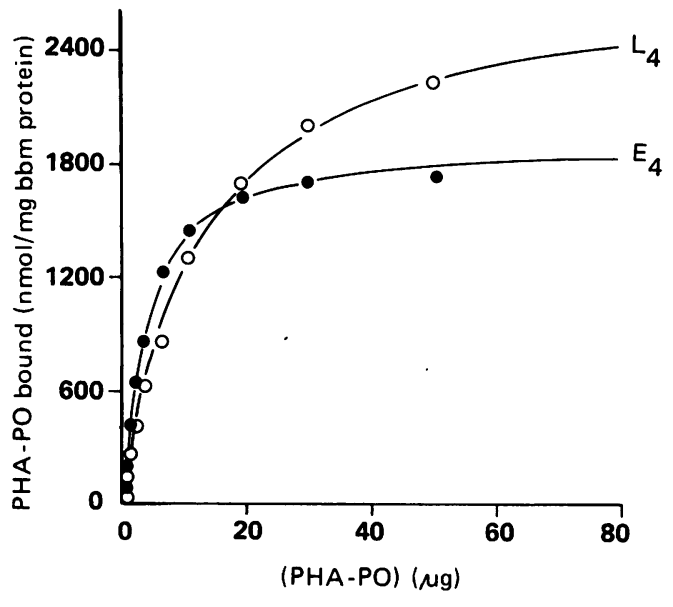

fixation and embedding procedures were as described above.

Statistical significance between the length of microvilli of control and PHA isolectin incubated Caco- 2 cells was assessed using an analysis of variance plus comparison of means. Statistical significance was accepted at the $\mathrm{p}<0.05$ level.

\section{Results}

BINDING OF PHASEOLUS VULGARIS ISOLECTINS $\mathrm{L}_{4}$ AND $E_{4}$ TO THE DIFFERENTIATED CACO-2 CELLS AND THEIR ISOLATED BRUSH BORDER MEMBRANE FRACTION

The specific binding of PHA- $\mathrm{L}_{4}$ and $\mathrm{PHA}^{-\mathrm{E}_{4}}$ to the brush border membranes of differentiated Caco-2 cells is shown in Figure 1. Computer analysis of the individual curves by means of iterised computer fit analysis of the data gave values for maximal binding per $\mathrm{mg}$ of brush border membrane protein and dissociation constants for both isolectins (Table I). The brush border membrane fraction had slightly more PHA- $\mathrm{L}_{4}$ than $\mathrm{PHA}-\mathrm{E}_{4}$ binding sites per $\mathrm{mg}$ of brush border membrane protein. The dissociation constant of PHA- $\mathrm{L}_{4}$ was four times greater than that of PHA-E $\mathrm{E}_{4}$. These data suggest that both PHA- $\mathrm{L}_{4}$ and PHA-E $\mathrm{E}_{4}$ are able to interact directly with the microvillous membranes of differentiated enterocyte like Caco- 2 cells.

Extracellular labelling with ferritin conjugated Phaseolus vulgaris isolectins $\mathrm{L}_{4}$ and $\mathrm{E}_{4}$, as indicated by ferritin particles, was evident on the surface of the Caco-2 cells (Fig 2). PHA-E Pinds $_{4}$ to the microvilli of the Caco- 2 cells to a greater extent than $\mathrm{PHA}_{-} \mathrm{L}_{4}$. Between the distribution of the ferritin particles, however, no differences

TABLE I Binding of peroxidase conjugated PHA- $L_{4}$ and $\mathrm{PHA}_{-} \mathrm{E}_{4}$ to purified brush border membranes of differentiated Caco-2 cells

\begin{tabular}{lll}
\hline & $\begin{array}{l}\text { Lectin binding/mg of brush } \\
\text { border membrane protein } \\
(\text { mean }(S D))(M)\end{array}$ & $\begin{array}{l}\text { Dissociation constant } \\
(\text { mean }(S D))(M)\end{array}$ \\
\hline $\mathrm{L}_{4}$ & $2540(151) .10^{9}$ & $4 \cdot 3(1 \cdot 4) \cdot 10^{-6}$ \\
$\mathrm{E}_{4}$ & $2104(140) .10^{-9}$ & $1 \cdot 1(0 \cdot 8) \cdot 10^{\circ}$ \\
\hline
\end{tabular}

The number of Phaseolus vulgaris isolectin binding sites in the brush border membrane has been established by means of iterised computer fit analysis of the data. ${ }^{20}$ The results are expressed as the mean $(\mathrm{SD})$ maximal binding and the mean (SD) dissociation constant of two different passages. could be detected. The ferritin particles are located almost exclusively over the glycocalyx of the microvilli and only a few are present over the cores of the microvilli.

Intracellular labelling was present in endocytotic vesicles over the apical cytoplasm of the Caco-2 cells (Fig 2).

INCORPORATION OF PRECURSORS FOR DNA, RNA, AND (GLYCO)PROTEIN SYNTHESIS BY DIFFERENTIATED CACO-2 CELLS AFTER INCUBATION WITH PHA-L $\mathrm{L}_{4}$ AND PHA-E When PHA- $_{4}$ was added to the culture medium and incubation was performed for 48 hours, the relative incorporation of ${ }^{14} \mathrm{C}$-thymidine and ${ }^{3} \mathrm{H}$ glucosamine seemed to increase with increasing lectin concentrations, whereas no change in the relative incorporation of ${ }^{14} \mathrm{C}$-uridine, ${ }^{35} \mathrm{~S}$ methionine, ${ }^{3} \mathrm{H}$-fucose, and $\mathrm{N}$-acetyl ${ }^{3} \mathrm{H}$ mannosamine could be observed (Fig 3). In comparison with PHA- $\mathrm{L}_{4}$, the stimulatory effect expressed as the relative incorporation of ${ }^{14} \mathrm{C}$ thymidine and ${ }^{3} \mathrm{H}$-glucosamine seemed to be significantly higher for PHA-E $\mathrm{E}_{4}$. Moreover, PHA-E $_{4}$ concentrations as low as $40 \mu \mathrm{g} / \mathrm{ml}$ already displayed a maximal stimulatory effect with respect to the relative incorporation of ${ }^{14} \mathrm{C}$ thymidine, whereas at the same lectin concentration the relative incorporation of ${ }^{3} \mathrm{H}$-glucosamine of PHA- $\mathrm{E}_{4}$ incubated cells was $85 \%$ greater than in control cells (Fig 3). As opposed to $\mathrm{PHA}-\mathrm{L}_{4}$, a noticeable increase of the relative incorporation of both ${ }^{35} \mathrm{~S}$-methionine and ${ }^{3} \mathrm{H}$-fucose was observed after incubation with PHA-E 4 . The increase in the relative incorporation of $\mathrm{N}$-acetyl ${ }^{3} \mathrm{H}$-mannosamine was only slight. The relative incorporation of ${ }^{14} \mathrm{C}$-uridine did not change irrespective of the PHA isolectin concentration.

The changes in the relative incorporation of ${ }^{14} \mathrm{C}$-thymidine, ${ }^{35} \mathrm{~S}$-methionine, ${ }^{3} \mathrm{H}$-glucosamine, ${ }^{3} \mathrm{H}$-fucose, and $\mathrm{N}$-acetyl ${ }^{3} \mathrm{H}$-mannosamine shown in Figure 3 vanished when the differentiated Caco- 2 cells were incubated with $200 \mu \mathrm{g}$ of heat inactivated $\mathrm{PHA}^{-\mathrm{E}_{4}} / \mathrm{ml}$ (15 minutes at $100^{\circ} \mathrm{C}$ ) (Table II).

Irrespective of the isolectin and lectin concentration, tested cell viability determined by trypan blue exclusion was $\geq 95 \%$. In addition, the DNA content per well (mean SD) seemed to be independent of the isolectin as well as lectin concentration tested $(64.9(3.9) \mu \mathrm{g}$ DNA/well for 0-200 $\mu \mathrm{g}$ of $\mathrm{PHA}^{-\mathrm{E}_{4}} / \mathrm{ml}$ and $62 \cdot 2(4 \cdot 1) \mu \mathrm{g}$ DNA/well for 0-200 $\mu \mathrm{g}$ of PHA- $\mathrm{L}_{4} / \mathrm{ml}$ ).

ULTRASTRUCTURAL CHANGES IN THE MICROVILLI OF DIFFERENTIATED CACO-2 CELLS AFTER INCUBATION WITH PHA-L 4 AND PHA-E Differentiated Caco-2 cells were exposed for 48 hours to $50 \mu \mathrm{g}$ of PHA- $\mathrm{L}_{4} / \mathrm{ml}$ or $50 \mu \mathrm{g}$ of PHA$E_{4} / \mathrm{ml}$. The ultrastructural morphology of the microvilli of these cells as well as control cells is shown in Figure 4.

In comparison with control Caco-2 cells and PHA- $\mathrm{L}_{4}$ incubated cells, the microvilli of PHA$E_{4}$ incubated cells clearly exhibited shortened microvilli (Fig 4). A morphometric analysis showed that the length of the microvilli of PHA$\mathrm{E}_{4}$ incubated cells differed significantly $(\mathrm{p}<0.01)$ from control cells (Table III). The length of the 


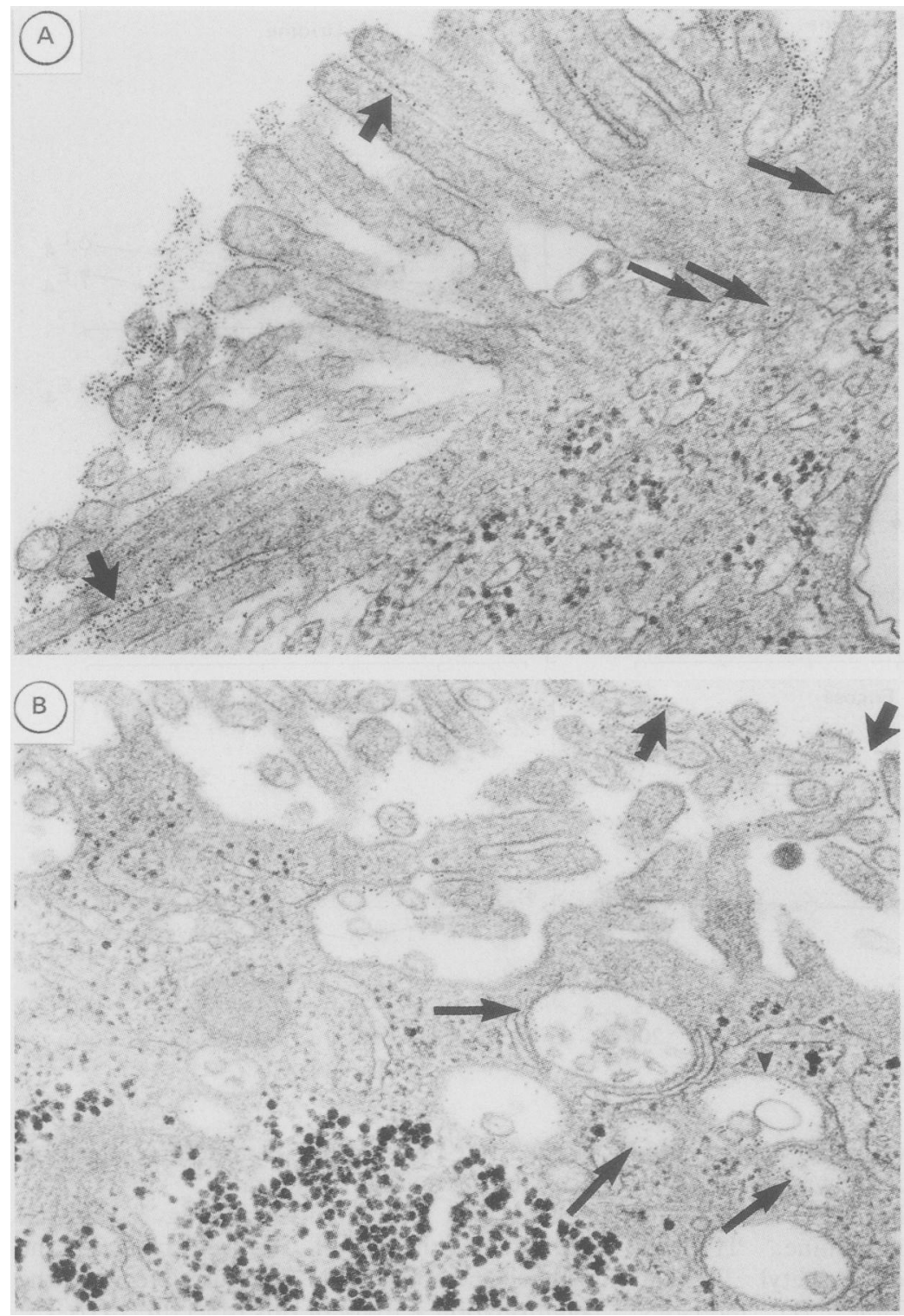

Figure 2: Binding of ferritin conjugated $\mathrm{PHA}-\mathrm{L}_{4}$ and $P H A-E_{4}$ to the microvilli of differentiated Caco-2 cells.

In comparison with PHA-E $E_{4}(A)$ the binding of $\mathrm{PHA}_{-} \mathrm{L}_{4}(\mathrm{~B})$ is less evident (arrows). Very few ferritin particles are present over the cores of the microvilli. Note the presence of ferritin particles in apical vesicles (small arrows). (Original magnification $\times 63050$.) microvilli of PHA- $\mathrm{L}_{4}$ incubated cells and control cells, however, did not differ significantly.

The brush borders of both PHA- $\mathrm{L}_{4}$ and PHA$\mathrm{E}_{4}$ incubated Caco- 2 cells contained membrane vesicles associated with the brush border (Fig 4). The brush borders of control Caco- 2 cells did not exhibit these membrane vesicles.

\section{Discussion}

One of the objectives of this study was to investigate the binding of the PHA isolectins $\mathrm{L}_{4}$ and $\mathrm{E}_{4}$ to isolated brush border membranes of Caco- 2 cells and intact Caco- 2 cells. The quantitative data of the binding of peroxidase conjugated isolectins to the brush border membranes are presented in Table I. Substantial differences between the dissociation constant of PHA- $\mathrm{L}_{4}$ and PHA-E 4 were determined. PHA- $\mathrm{E}_{4}$, the erythroagglutinating isolectin, recognises biantennary oligosaccharides, whereas $\mathrm{PHA}^{-\mathrm{L}_{4}}$, the leukoagglutinating isolectin, binds specifically to tri- and tetra-antennary oligosaccharides. ${ }^{22}$ This variety in oligosaccharide specificity between PHA- $\mathrm{L}_{4}$ and PHA-E $\mathrm{E}_{4}$ seems to be expressed in the differences of the dissociation constants. In comparison with $\mathrm{PHA}-\mathrm{E}_{4}$, the dissociation constant of $\mathrm{PHA}^{-\mathrm{L}_{4}}$ for isolated brush border membranes of differentiated Caco2 cells is four times greater. Binding studies in the published reports mention higher values for the association constants of the lectins (reciprocal value of dissociation constants). Association constants of $12 \cdot 6.10^{6} \mathrm{M}^{-1}$ for $\mathrm{PHA}^{-\mathrm{L}_{4}}$ and $2 \cdot 5.10^{6}$ $\mathrm{M}^{-1}$ for PHA-E $\mathrm{E}_{4}$ are calculated for the binding to purified rat brush border membranes. ${ }^{23}$ The different cell types from which brush border membranes were isolated might explain these different values to a great extent.

By electron microscope immunocytochemistry, immunogold localisation of ingested PHA- $\mathrm{L}_{4}$ and PHA-E $\mathrm{E}_{4}$ was shown on the duodenal and jejunal microvilli and endocytosed into the lysosomal pathways of the rat enterocytes. ${ }^{1+}$ Recently, direct experimental evidence has been presented showing transepithelial transport and uptake of dietary PHA into the systemic circulation of the rat..$^{2+}$ In addition, our binding experiments showed that after incubation for 30 minutes with ferritin conjugated isolectins, ferritin particles were present extracellularly on the microvilli of Caco-2 cells and intracellularly over apical invaginations and vesicles (Fig 2). The short time exposure of Caco-2 cells to PHA$\mathrm{L}_{4}$ or PHA-E $\mathrm{E}_{4}$ together with the different dissociation constants may explain the variety in binding of the isolectins.

In in vivo studies the incorporation of precursors in enterocytes is dependent on a direct action of the lectin on enterocyte metabolism as well as on an indirect effect mediated through the reduction of food intake. ${ }^{25}$ In this in vitro study the direct interference of PHA isolectins with the cellular metabolism of differentiated Caco- 2 cells can be investigated. To detect any differences in their effect upon the cellular metabolism, PHA$\mathrm{L}_{4}$ and PHA-E $\mathrm{E}_{4}$ were tested separately. Since incubation was performed with the very same concentrations, the results clearly show that PHA-E ${ }_{4}$ stimulates the incorporation of ${ }^{14} \mathrm{C}$ thymidine, ${ }^{35} \mathrm{~S}$-methionine, ${ }^{3} \mathrm{H}$-glucosamine, ${ }^{3} \mathrm{H}$-fucose, and $\mathrm{N}$-acetyl ${ }^{3} \mathrm{H}$-mannosamine to a greater extent than $\mathrm{PHA}_{4} \mathrm{~L}_{4}$ (Fig 3; Table II). After incubation of differentiated Caco-2 cells with heat inactivated $\mathrm{PHA}-\mathrm{E}_{4}$ (15 minutes at $100^{\circ} \mathrm{C}$ ), the stimulatory effect of $\mathrm{PHA}^{-\mathrm{E}_{4}}$, resulting in an increased incorporation of radioactive precursors, disappears (Table II). This finding indicates that the stimulatory effect was related to $\mathrm{PHA}-\mathrm{E}_{4}$ binding to the specific biantennary oligosaccharide ${ }^{22}$ on the cell surface membrane of differentiated Caco- 2 cells.

Prolonged exposure of the rat intestinal cells to PHA is known to result in stimulation of the cellular metabolism. ${ }^{911-13}$ Also, our incorporation experiments suggest that exposure for 48 hours to PHA-E 4 results in stimulation of DNA and (glyco)protein synthesis in differentiated Caco-2 cells. However, in contrast to another investigation, ${ }^{13}$ neither $\mathrm{PHA}-\mathrm{L}_{4}$ nor $\mathrm{PHA}-\mathrm{E}_{4}$, is able to enhance the incorporation of ${ }^{14} \mathrm{C}$-uridine in Caco- 2 cells. The DNA content per well does not change significantly with increasing lectin concentration. Moreover, cell viability remains rather constant $(\geq 95 \%)$. For that reason DNA synthesis most probably does not account for the increased incorporation of ${ }^{1+} \mathrm{C}$-thymidine. 
Figure 3: Relative incorporation of ${ }^{1+} \mathrm{C}$ thymidine, ${ }^{1+} \mathrm{C}$-uridine ${ }^{35} \mathrm{~S}$-methionine, ${ }^{3} \mathrm{H}$ glucosamine, ${ }^{3} \mathrm{H}$-fucose, and $N$-acetyl ${ }^{3} H$-mannosamine by differentiated Caco-2 cells after incubation with $\mathrm{PHA}_{-} \mathrm{L}_{4}$ or PHA-E Two different passages have been used to establish the effect of $\mathrm{PHA}-\mathrm{L}_{4}$ and $P H A-E_{4}$. The results are expressed as the mean (SEM) relative incorporation. The dotted area represents the mean (SEM) relative incorporation of cell cultures which are not incubated with lectins. For each passage of the cells the relative incorporation of all lectin concentrations was determined using quadruplicate cultures.
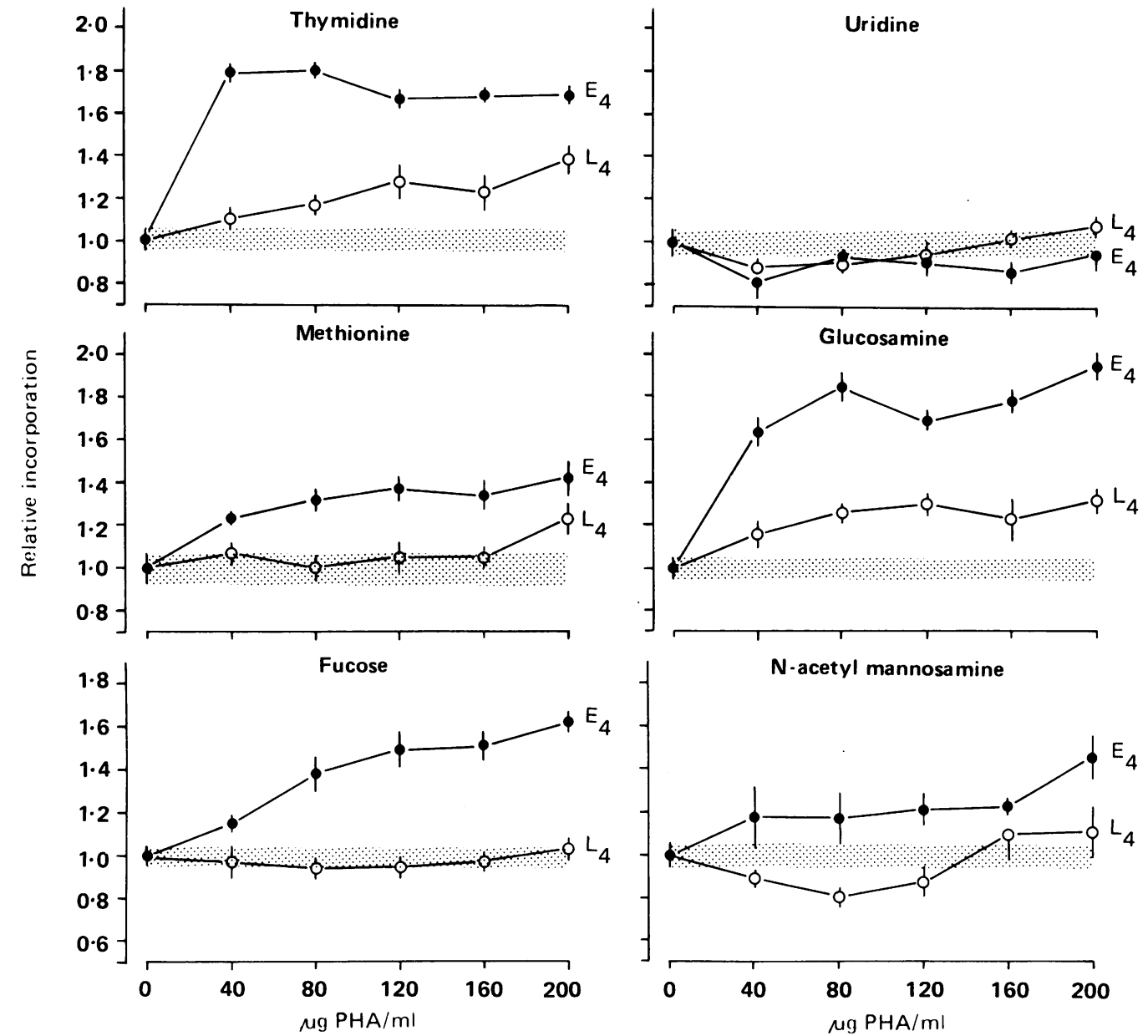

Whether the incorporation is due to increased DNA repair is presently unknown.

In the presence of $P H A-E_{4}$, the relative incorporation of ${ }^{35} \mathrm{~S}$-methionine, ${ }^{3} \mathrm{H}$-glucosamine, ${ }^{3} \mathrm{H}$-fucose, and $\mathrm{N}$-acetyl ${ }^{3} \mathrm{H}$-mannosamine (Fig 3; Table II) increases, reflecting sustained synthesis of (glyco)proteins. At the same time the relative incorporation of ${ }^{14} \mathrm{C}$-uridine does not change compared with control Caco- 2 cells. Therefore, the data presented here suggest that the increased rate of synthesis of (glyco)proteins is due to a translational rather than transcriptional control of (glyco)protein synthesis. In contrast to Ricinus communis agglutinin (ricin and abrin), which after endocytosis inactivates the $60 \mathrm{~S}$ ribosomal units, ${ }^{26}$ PHA-E ${ }_{4}$ might speed up (glyco)protein synthesis by assembling functional polysomes, increasing

TABLE II The effect of heat inactivated $\mathrm{PHA}-\mathrm{E}_{4}$ on the relative incorporation of radioactive precursors by differentiated Caco-2 cells

\begin{tabular}{|c|c|c|}
\hline \multirow[b]{2}{*}{ Precursor } & \multicolumn{2}{|c|}{ Relative incorporation } \\
\hline & $\begin{array}{l}\text { No heat treatment } \\
\text { of } P H A-E_{4}\end{array}$ & $\begin{array}{l}\text { Heat inactivated } \\
P_{H A-E_{4}}\end{array}$ \\
\hline $\begin{array}{l}{ }^{14} \mathrm{C} \text {-thymidine } \\
{ }^{1+} \mathrm{C} \text {-uridine } \\
{ }^{35} \text { - methionine } \\
{ }^{3} \mathrm{H} \text {-glucosamine } \\
{ }^{\mathrm{H}} \text {-fucose } \\
\mathrm{N} \text {-acetyl }{ }^{3} \mathrm{H} \text {-mannosamine }\end{array}$ & $\begin{array}{l}1.71(0.04) \\
0.95(0.07) \\
1.45(0.02) \\
1.96(0.09) \\
1.62(0.04) \\
1.45(0.10)\end{array}$ & $\begin{array}{l}1.03(0.06) \\
1.05(0.07) \\
1.00(0.03) \\
1.02(0.05) \\
0.99(0.05) \\
1.01(0.06)\end{array}$ \\
\hline
\end{tabular}

Two different passages have been used to establish the effect of heating. The results are expressed as the mean (SEM) relative incorporation. For each passage of the cells the relative incorporation of PHA-E ${ }_{4}$ and heat treated PHA-E $4(200 \mu \mathrm{g} / \mathrm{ml})$ was determined using quadruplicate cultures. the net rate of initiation of protein synthesis or accelerating the translation rate.

The data presented here (Fig 3) further indicate that the PHA- $\mathrm{L}_{4}$ induced changes in the cellular metabolism do not correlate with the agglutination activity of this isolectin. $\mathrm{PHA}^{-\mathrm{L}_{4}}$, which does not possess any haemagglutinating activity at concentrations lower than $500 \mu \mathrm{g} / \mathrm{ml}$, clearly acts upon the incorporation of ${ }^{14} \mathrm{C}$ thymidine and ${ }^{3} \mathrm{H}$-glucosamine by differentiated Caco- 2 cells.

The results of several experiments have shown that exposure of rat intestinal epithelium to concanavalin $\mathrm{A}$, wheat germ agglutinin, and kidney bean ( $P$ vulgaris) lectin causes disarrangement of the cytoskeleton of rat enterocytes. ${ }^{3-527}$ Recently, actin cytoskeletal lesions resulting in shortened microvilli have been found in differentiated Caco- 2 cells after exposure to soybean agglutinin. ${ }^{\text {is }}$ Shortening of the microvilli seemed to be accomplished by a shift in the ratio of globular:filamentous actin. As a result of exposure of differentiated Caco-2 cells to PHA$E_{4}$ for 48 hours, the lengths of the microvilli of these cells were shortened significantly $(\mathrm{p}<0.01)$ in comparison with control and PHA-L incubated cells (Fig 4 and Table III). It is therefore tempting to suggest that the PHA-E induced shortening of the length of the microvilli has to be attributed to actin cytoskeletal lesions as well. After exposure of rat intestinal epithelium to intraluminal dietary lectins clusters of vesicles associated with the brush border can be found. ${ }^{45}$ Also, in vitro an increased number of vesicles nearby the brush borders of PHA- $\mathrm{L}_{4}$ and 
Figure 4: Microvilli of differentiated Caco-2 cells after incubation with $P H A$ $L_{4}$ and $P H A-E_{4}$ Microvilli of control Caco-2 cells $(A)$. Microvill of Caco-2 cells after incubation for 48 hours with $50 \mu \mathrm{g}$ of $\mathrm{PHA}_{\mathrm{H}} \mathrm{L}_{4} / \mathrm{ml}(\mathrm{B})$ or $50 \mu \mathrm{g}$ of $P H A-E_{4} / \mathrm{ml}(C)$. Original magnification $\times 32500$.
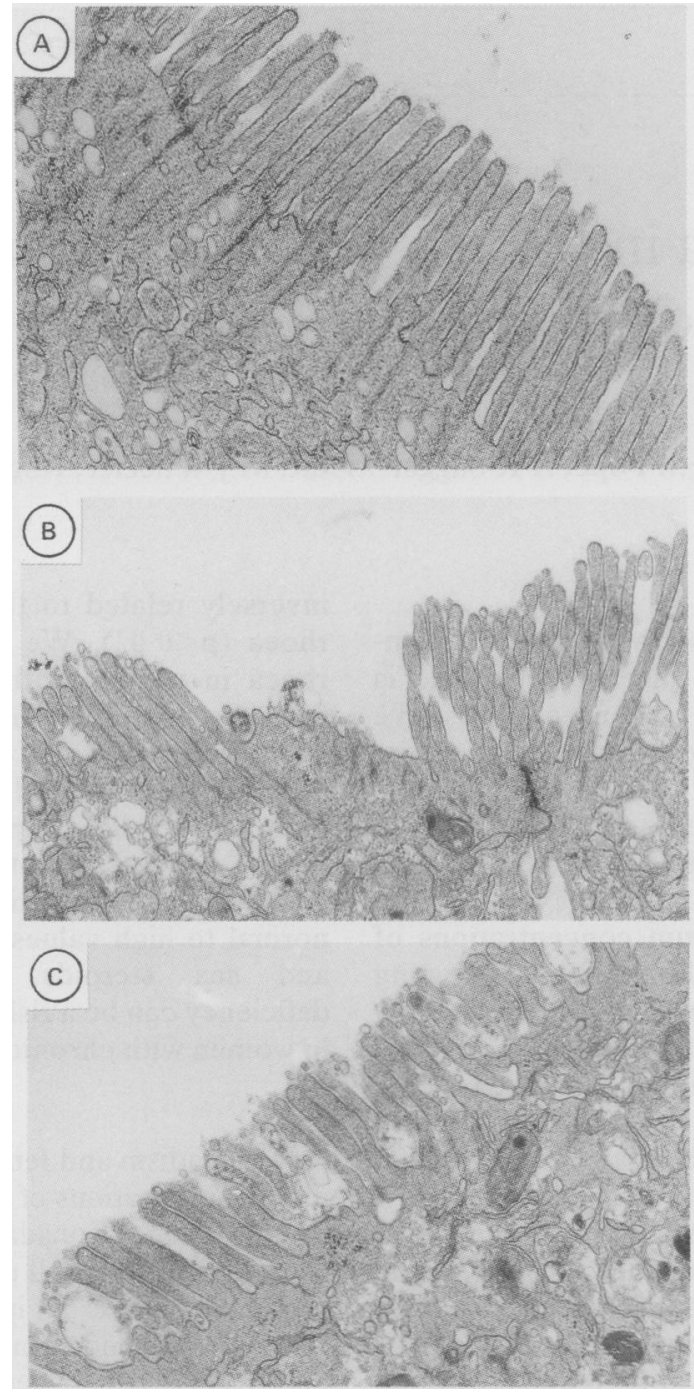

PHA-E 4 incubated Caco- 2 cells was observed (Fig 4). The presence of these vesicles may reflect an increased turnover of the microvillous membrane.

After binding of the PHA isolectins to the brush border membrane receptors of differentiated Caco- 2 cells and internalisation of bound lectin, PHA- $\mathrm{L}_{4}$ as well as PHA-E $\mathrm{E}_{4}$ induce a number of cell metabolic changes within the cells. The precise mechanism responsible for the stimulation of the cellular metabolism has not been clarified. Further experiments are necessary to elucidate the nature of the regulatory mechanisms of these events.

The authors greatly appreciate the expert technical assistance of Ton Ultee and the help of Dr Jan Raaijmakers with the compute analysis of the data (ELLSA). We would like to express ou gratitude to Hanneke de Waal for drawing the figures, to Harry Otter for the preparation of the photographs, and to Marijke van Dijk for typing the manuscript.

1 Liener IE. Phytohemagglutinins: their nutritional significance. $\mathcal{F}$ Agric Food Chem 1974; 22: 17-22.

2 Liener IE. Significance for humans of biologically active factors in soybeans and other food legumes. $7 \mathrm{Am}$ Oil Chem Soc 1979; 56: 121-9.

3 King TP, Pusztai A, Clarke EMW. Kidney bean (Phaseolus vulgaris) lectin-induced lesions in rat small intestine: ligh vulgaris) lectin-induced lesions in rat small intestine:

4 King TP, Pusztai A, Clarke EMW. Kidney bean (Phaseolu vulgaris) lectin-induced lesions in rat small intestine: 3 . Ultrastructural studies. F Comp Pathol 1982; 92: 357-73.
TABLE III Changes in microvillus length of differentiated Caco-2 cells after incubation with $P H A$ isolectins $L_{4}$ and $E_{4}$

\begin{tabular}{ll}
\hline Caco-2 cells & $\begin{array}{l}\text { Length of the microvilli }(\mu \mathrm{m}) \\
(\text { mean }(S E M))\end{array}$ \\
\hline Controls & $2 \cdot 01(0 \cdot 05)$ \\
PHA-L $_{4}$ incubated & $1.91(0.06)$ \\
PHA-E $_{4}$ incubated & $1 \cdot 35(0.04)$ \\
\hline
\end{tabular}

Three different passages were used to measure the isolectin induced alterations of the microvilli. Differentiated Caco- 2 cells
were incubated for 24 hours with $50 \mu \mathrm{g}$ of PHA-L $/ \mathrm{ml}$ or $50 \mu \mathrm{g}$ of were incubated for 24 hours with $50 \mu \mathrm{g}$ of $\mathrm{PHA}-\mathrm{L}_{4} / \mathrm{ml}$ or $50 \mu \mathrm{g}$ of
$\mathrm{PHA}-\mathrm{E}_{4} / \mathrm{ml}$. Microvillus length between control cells and $\mathrm{PHA}-\mathrm{E}_{4}$ incubated cells differed significantly $(p<0 \cdot 01)$. No significant difference was found between control cells and $\mathrm{PHA}_{\mathrm{L}} \mathrm{L}_{4}$ incubated cells.

5 Lorenzsonn V, Olson WA. In vivo responses of rat intestinal epithelium to intraluminal dietary lectins. Gastroenterology 1982; 82: 838-48.

6 Lis H, Sharon N. Biological properties of lectins. In: Liener IE, Sharon N, Goldstein IJ, eds. The lectins: properties, functions and applications in biology and medicine. OrlandoToronto: Academic Press Inc, 1986: 265-91.

7 Hume DA, Weidemann MJ. Mitogenic lymphocyte transformation. Amsterdam: Elsevier/North-Holland Biomedical tion. Amsterd 1980.

8 Banwell JG, Boldt DH, Meyers J, Weber FL Jr. Phytohemagglutinin derived from red kidney bean (Phaseolus vulgaris): a cause for intestinal malabsorption associated with bacterial overgrowth in the rat. Gastroenterology 1983; 84: 506-15.

9 Greer F, Brewer AC, Pusztai A. Effect of kidney bean (Phaseolus vulgaris) toxin on tissue weight and composition and some metabolic functions of rats. Br $\mathcal{F}$ Nutr 1985; 54: 95-103.

10 Donatucci DA, Liener IE, Gross CJ. Binding of navy bean (Phaseolus vulgaris) lectin to the intestinal cells of the rat and its effect on the absorption of glucose. $\mathcal{F}$ Nutr 1987; 117: $2154-60$.

11 Palmer RM, Pusztai A, Bain P, Grant G. Changes in rates of tissue protein synthesis in rats induced in vivo by consumption of kidney bean lectins. Comp Biochem Physiol 1987; 88C: $179-83$.

12 Oliveira JTA de, Pusztai A, Grant G. Changes in organs and tissues induced by feeding of purified kidney bean (Phaseolus vulgaris) lectin. Nutr Res 1988; 8: 943-7.

13 Pusztai A, Oliveira JTA de, Bardocz S, Grant G, Wallace HM. Dietary kidney bean lectin-induced hyperplasia and increased polyamine content of the small intestine. In: BøgHansen TC, Freed DLJ, eds. Lectins: biology, biochemistry, clinical biochemistry. Volume 6. St Louis: Sigma Library, 1988: 117-20.

14 King TP, Pusztai A, Grant G, Slater D. Immunogold localization of ingested kidney bean (Phaseolus vulgaris) lectins in epithelial cells of the rat small intestine. Histochem $\mathcal{F} 1986$; 18: 413-20.

15 Draaijer M, Koninkx J, Hendriks H, Kik M, van Dijk J, Mouwen J. Actin cytoskeletal lesions in differentiated human colon carcinoma Caco-2 cells after exposure to soybean agglutinin. Biol Cell 1989; 65: 29-35.

16 Pinto M, Robine-Leon S, Appay MD, et al. Enterocyte-like differentiation and polarization of the human colon carcinoma cell line Caco-2 in culture. Biol Cell 1983; 47: 323-30.

17 Corfield AP, Schauer R. Current aspects of glycoconjugate biosynthesis. Biol Cell 1979; 36: 213-26.

$18 \mathrm{Labarca} C$, Paigen $\mathrm{K}$. A simple, rapid and sensitive DNA assay procedure. Anal Biochem 1980; 102: 344-52.

19 Schmitz J, Preiser H, Maestracci D, Ghosh BK, Cerda JJ, Crane RK. Purification of the human intestinal brushborder membrane. Biochim Biophys Acta 1973; 323: 98-112.

20 Hendriks HGCJM, Koninkx JFJG, Draaijer M, van Dijk JE, Raaijmakers JAM, Mouwen JMVM. Quantitative determination of the lectin binding capacity of small intestinal brush-border membrane. An enzyme-linked lectin sorben assay (ELLSA). Biochim Biophys Acta 1987; 905: 371-5.

21 Perre J, Foncin JF. An embedding method for monolayer cell cultures for light and electron microscopy. Stain Technol cultures for light

$22 \mathrm{Lis} \mathrm{H}$, Sharon N. Lectins as molecules and as tools. Ann Rev Biochem 1986; 55: 35-67.

23 Boldt DH, Banwell JG. Binding of isolectins from red kidney bean (Phaseolus vulgaris) to purified rat brush-border membranes. Biochim Biophys Acta 1985; 843: 230-7.

24 Pusztai A, Greer F, Grant G. Specific uptake of dietary lectins into the systemic circulation of the rats. Biochem Soc Trans 1989; 17: 481-2.

25 Lafont J, Rouanet JM, Gabrion J, Assouad JL, Zambonino Infante JL, Besançon P. Duodenal toxicity of dietary Phaseolus vulgaris lectins in the rat: an integrative assay. Digestion 1988; 41: 83-93.

26 Olsnes S, Refsnes K, Pihl A. Mechanism of action of the toxic lectins abrin and ricin. Nature 1974; 249: 627

27 Sjölander A, Magnusson KE, Latkovic S. Morphological changes of rat small intestine after short-time exposure to changes of rat small intestine after short-time exposure to 1986; 11: 285-93. 